\title{
Tingkat Kinerja Karyawan Dan Faktor-Faktor Yang Mempengaruhi Kinerja Karyawan Yang Bekerja Dari Rumah (Work From Home) Selama Masa Pandemi Covid 19
}

\section{Maria Rombe ${ }^{*}$, Johnson Dongoran ${ }^{2}$}

1,2 Universitas Kristen Satya Wacana, Salatiga, Indonesia

\section{ART ICLE INFO}

\section{Article history:}

Received August 02, 2021

Revised August 09, 2021

Accepted September 30, 2021

Available online October 25, 2021

Kata Kunci:

Kinerja Karyawan, Faktor Kinerja Karyawan

Keywords:

Employee Performance, Employee

Performance Factor

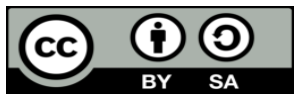

This is an open access article under the $\mathrm{CC}$ BY-SA license.

Copyright (c) 2021 by Author. Published by Universitas Pendidikan Ganesha.

\begin{abstract}
A B S T R A K
Kinerja karyawan menjadi tindakan nyata yang ditampilkan sebagai hasil kerja yang telah dikerjakan oleh karyawan sesuai dengan perannya dalam suatu organisasi atau perusahaan. Penelitian ini bertujuan untuk menganalisis tingkat kinerja karyawan dan mengidentifikasi faktor-faktor yang mempengaruhi kinerja karyawan yang bekerja dari rumah selama pandemi Covid-19. Jenis penelitian ini merupakan penelitian kualitatif. Teknik pengambilan sampel menggunakan metode purposive sampling yaitu responden yang benar-benar bekerja dari rumah selama pandemi Covid-19 dengan jumlah 10 karyawan. Jenis data yang digunakan dalam penelitian ini adalah data primer yang diperoleh langsung dari jawaban responden melalui kuesioner. Data dianalisis menggunakan teknik analisis deskkriptif kualitatif. Hasil penelitian menunjukkan bahwa tingkat kinerja karyawan menurun atau kurang maksimal. Sedangkan faktor-faktor yang mempengaruhi kinerja karyawan yaitu motivasi, bonus, punishment, usia, latar belakang pendidikan, pengalaman kerja, latar belakang sosial budaya, lingkungan kerja, kepemimpinan, umpan balik rekan kerja, pengawasan dari atasan serta sistem upah. Adapun faktor lain yang mempengaruhi kinerja yaitu jaringan internet yang kurang stabil, fasilitas kurang memadai, kepuasan kerja, target penjualan, ruang gerak terbatas dan miskomunikasi.
\end{abstract}

\section{A BS TRACT}

Employee performance is a real action that is displayed as a result of work that has been done by employees in accordance with their role in an organization or company. The purpose of this study was determining the level of employee performance and identify the factors that affect the performance of employees working from home during the Covid-19 pandemic. This type of research is qualitative research to 10 employees at Perum Perumnas Regional VII Makassar. The sampling technique used purposive sampling method, namely respondents who actually worked from home during the Covid-19 pandemic. The type of data used in this study is primary data obtained directly from respondents' answers through questionnaires. The questionnaire used is an open questionnaire. Data were analyzed using qualitative descriptive analysis techniques. The results showed that the level of employee performance decreased or was less than optimal. While the factors that affect employee performance are motivation, bonuses, punishment, age, educational background, work experience, socio-cultural background, work environment, leadership, peer feedback, supervision from superiors and the wage system. As for other factors that affect performance, namely the internet network is less stable, inadequate facilities, job satisfaction, sales targets, limited space and miscommunication.

\section{PENDAHULUAN}

Virus Corona atau biasa disebut Covid-19 (Corona Virus Disease 2019) ditemukan pertama kali di Kota Wuhan, China pada akhir Desember 2019 (Marroquín et al., 2020; Talevi et al., 2020). Pada jangka waktu yang relatif singkat, virus ini dengan sangat cepat menyebar ke hampir seluruh negara di dunia, termasuk Indonesia (Arief Kresna dan Juni Ahyar, 2020; Muhyiddin, 2020). Untuk menghambat pertumbuhan infeksi yang semakin cepat, perubahan dalam kebiasaan sosial inti warga diperlukan dan perubahan perilaku ini harus terjadi dengan sangat cepat. Kontribusi kali ini mengkaji motivasi psikologis di balik dua tindakan perilaku yang diterapkan selama Pandemi Covid-19: jarak fisik, yaitu meminimalkan kontak dekat dengan orang lain (Social and Physical Distancing) dan kedua memakai masker wajah. Baik menjaga jarak secara fisik maupun menggunakan masker wajah dapat mengurangi risiko kemungkinan bahwa orang yang terinfeksi menyebarkan virus SARS-CoV-2 kepada mereka yang tidak terinfeksi (Lau et al., 2020; Pfattheicher et al., 2020). Social and Physical Distancing atau pembatasan interaksi secara fisik antar individu memberi dampak ke berbagai hal salah satunya penerapan sistem Work From Home (Bukhari et al., 2019; Koh et al., 2020). Ini terjadi karna aktivitas masyarakat dibatasi secara fisik untuk memutus 
mata rantai penyebaran virus Covid-19. Bekerja jarak jauh dimaksudkan sebagai cara bekerja dalam sebuah organisasi atau perusahaan yang dilaksanakan sebagian atau seluruhnya di luar kantor dengan bantuan layanan telekomunikasi dan informasi (Mungkasa, 2020; Purwanto, 2020).

Pemerintah menghimbau semua lapisan masyarakat agar dapat melakukan kegiatan yang biasa dilakukan di luar rumah, seperti bekerja, belajar dan beribadah bisa dilaksanakan dari rumah (Work From Home) untuk memutus mata rantai penularan Covid-19 (Arianto, 2021; Tuwinanto \& Rahadi, 2021). Akibat pandemi covid-19 sebagian besar perusahaan-perusahaan milik negara maupun swasta menerapkan konsep Work From Home melalui kebijakan-kebijakan yang disepakati bersama karyawannya untuk tetap bekerja secara produktif dan menyelesaikan pekerjaan tepat waktu dengan memanfaatkan teknologi (Endah Yuliani \& Romadhiyana Kisno Saputri, 2021; Muhyiddin, 2020). Seperti menggunakan media online (google meet, zoom dan aplikasi lain) yang dapat menghubungkan antar individu karyawan dalam menyelesaikan pekerjaan tanpa harus berinteraksi secara fisik (Nasution et al., 2020; Wijonarko et al., 2020). Sebagian karyawan yang bekerja diperusahaan tersebut ada yang dirumahkan sementara dan ada juga yang bekerja di rumah (Work From Home). Setiap Perusahaan pasti mempunyai tujuan yang berbeda antara perusahaan yang satu dengan perusahaan lainnya. Dalam pencapaian tujuan tersebut, banyak berbagai faktor-faktor yang terlibat dalam pencapaian tersebut. Dalam hal ini faktor yang berpengaruh penting adalah sumber daya manusia.

Selain itu setiap perusahaan juga membutuhkan tenaga dan pikiran yang berasal dari sumber daya manusia. Untuk menunjukan tenaga dan pikiran SDM harus mampu menunjukan kinerja kerjanya kepada perusahaan(Filatrovi et al., 2021; Hermawati \& Indriyani, 2019). Kinerja karyawan sangat dibutuhkan dalam melakukan aktivitas perusahaan. Dalam perusahaan biasanya kinerja karyawan ada yang baik dan ada yang buruk. Semua hal tersebut tergantung dari masing-masing individu karyawan tersebut. Setiap perusahaan tentunya ingin mendapatkan kinerja karyawan yang baik dalam setiap bidang masing-masing. Kinerja karyawan yang diharapkan dapat menghasilkan mutu pekerjaan yang baik serta jumlah pekerjaan yang sesuai dengan standard (Astuti et al., 2019; Nasrih, 2016; Syatoto, 2018). Temuan penelitian sebelumnya menyatakan pegawai tetap menginginkan bekerja dari rumah begitu juga dari data kaji cepat Asture Solution (Mungkasa, 2020). Karyawan merasa lebih produktif dalam skema Work From Home (Darmalaksana et al., 2020). Produktivitas pekerja yang bekerja dari rumah tinggi. Penelitian ini fokus pada tingkat kinerja dan faktor-faktor yang mempengaruhi kinerja karyawan selama Pandemi Covid-19. Tujuan Penelitian ini yaitu untuk mengetahui tingkat kinerja karyawan dan mengidentifikasi faktor-faktor yang mempengaruhi kinerja karyawan yang bekerja dari rumah selama pandemi Covid-19.

\section{METODE}

Metode penelitian yang digunakan dalam penelitian ini adalah jenis penelitian kualitatif Hennink, M. (2011). Pengambilan data dilakukan di Perum Perumnas Regional VII Makassar, karna targetnya untuk mengetahui tingat kinerja dan faktor-faktor yang mempengaruhi kinerja karyawan yang bekerja dari rumah selama pandemi Covid-19. Dalam penelitian ini menggunakan data primer yang diperoleh langsung dari jawaban responden melalui kuesioner. Kuesioner yang digunakan dalam penelitian ini merupakan jenis kuesioner terbuka dimana jawabannya di isi oleh responden sehingga mendapat informasi yang mendalam. Data dianalisis menggunakan teknik analisis deskriptif. Penelitian ini menggunakan 10 narasumber. Sampel sumber data yang digunakan adalah purposive sampling. Deddy Dyas Cahyono et al,. (2016) mengatakan purposive sampling adalah teknik penentuan sampling yang disesuaikan dengan tujuan penelitian. Narasumber yang ditunjuk adalah karyawan yang benar-benar melaksanakan konsep Work From Home (bekerja dari rumah) selama pandemi Covid-19 sehingga mampu memberikan data yang optimal.

\section{HASIL DAN PEMBAHASAN}

\section{Hasil}

Berdasarkan hasil penelitian terkait ketepatan waktu semua responden mengatakan mengerjakan tugas tepat waktu selama bekerja dari rumah. Adapun inisiatif kerja selama bekerja dari rumah (work from home), semua responden mengatakan memiliki inisiatif kerja. Karna sikap inisiatif merupakan kemampuan diri untuk lebih produktif melakukan sesuatu, khususnya penyelesaian pekerjaan. Dengan adanya sikap inisiatif kerja selama bekerja dari rumah memampukan karyawan mengerjakan tugas tepat waktu. Dari jawaban responden tersebut dapat dikatakan bahwa karyawan memiliki insiatif kerja selama bekerja dari rumah (work from home). Selanjutnya pengaruh penggunaan sumber daya yang digunakan dalam bekerja dari rumah (work from home), semua responden mengatakan sangat mempengaruhi. Karna penggunaan listrik dan internet bertambah serta terbatasnya 
jaringan serta kuota internet. Dari pendapat responden tersebut dapat diketahui bahwa penggunaan sumberdaya karyawan selama bekerja dari rumah (work from home) sangat mempengaruhi.

Hasil kerja karyawan selama bekerja dari rumah (work from home), sebanyak enam responden mengatakan hasil kerja belum sesuai karna belum mencapai target yang diberikan. Sedangkan empat responden yang mengatakan sesuai sudah mencapai target selama bekerja dari rumah (work from home). Dari jawaban responden tersebut dapat dikatakan bahwa hasil kerja karyawan Pada Perum Perumnas Regional VII Makassar belum sesuai karna belum mencapai target. Adapun mutu hasil kerja karyawan selama bekerja dari rumah (work from home), enam responden mengatakan menurun atau kurang baik. Tiga responden yang mengatakan menurun, karna terkendala jaringan sehingga koordinasi terkait pekerjaan agak lambat. Tiga responden lain mengatakan mutu kurang baik dibandingkan Work From Office (bekerja dari kantor), karna kurang fokus bekerja dari rumah. Sedangkan empat responden menjawab mutu hasil kerja baik karna mencapai target yang diharapkan. Dari jawaban responden tersebut dapat dikatakan bahwa mutu hasil kerja karyawan menurun atau kurang maksimal. Sedangkan bentuk kerjasama karyawan dengan atasan dan rekan kerja selama bekerja dari rumah (work from home), sembilan responden mengatkan baik dengan memanfaatkan alat teknologi seperti Via Whatsapp dan Zoom untuk berkoordinasi terkait pekerjaan. Sedangkan satu responden yang mengatakan kurang baik karna terkendala jaringan internet yang kurang stabil pada saat menggunakan aplikasi zoom untuk berkoordinasi. Dari jawaban responden tersebut dapat dikemukakan bahwa bentuk kerjasama karyawan dengan atasan dan rekan kerja baik melalui Via Whatsapp dan Zoom.

Faktor-faktor yang mempengaruhi kinerja karyawan yang bekerja dari rumah (work from home) selama masa pandemi Covid-19. Pertama, faktor bonus, Sembilan responden mengatakan bonus mempengaruhi kinerja. Karna selama bekerja dari rumah pencapaian target kurang maksimal sehingga berdampak pada pemberian bonus serta uang makan dan transport terpotong. Sedangkan satu responden yang mengatakan tidak mempengaruhi. Karna situasi pandemi yang mengharuskan bekerja dari rumah demi kebaikan bersama dan kesehatan itu lebih penting dari materi. Bonus itu merupakan apresiasi terhadap kinerja bukan menjadi dasar kinerja yang ditunjukkan. Dari jawaban responden tersebut dapat dikatakakan bahwa bonus mempengaruhi kinerja karyawan. Kedua faktor punishment, sembilan responden mengatakan mempengaruhi. Karna pada saat mendapatkan sanksi akan berpengaruh dalam penilaian kinerja yang akan mengalami penurunan. Dengan adanya sanksi karyawan dapat mengetahui dimana letak kesalahan dalam bekerja dan sebisa mungkin kesalahan yang sama tidak terulang lagi. Sedangkan satu responden mengatakan tidak mempengaruhi karna sanksi yang diterima merupakan hasil tindakan sendiri yang harus dipertanggungjawabkan. Dari jawaban responden tersebut dapat dikatakan bahwa punishment mempengaruhi kinerja karyawan.

Ketiga faktor usia, enam responden mengatakan mempengaruhi. Karna belum mahir dalam mengoperasikan aplikasi Zoom selama bekerja dari rumah (work from home). Sedangkan empat responden yang mengatakan tidak mempengaruhi karna usia tidak menjadi hambatan selama motivasi dan loyalitas tetap dipegang teguh. Dari jawaban responden tersebut dapat dikatakan bahwa usia mempengaruhi kinerja karyawan. Adapun faktor latar belakang pendidikan, delapan responden yang mengatakan mempengaruhi karna latar belakang pendidikan merupakan salah satu kualifikasi untuk mengerjakan pekerjaan tertentu. Khususnya dalam penggunaan aplikasi AT pada Perum Perumnas Regional VII Makassar. Apabila latar pendidikan tidak sesuai dengan bidang yang kita tempati maka akan berdampak pada kinerja. Sedangkan dua responden yang mengatakan tidak mempengaruhi karna memiliki latar belakang pendidikan yang tidak sesuai dengan posisinya namun dapat menyelesaikan tugas yang diberikan dengan baik. Intinya mau belajar. Dari jawaban responden tersebut dapat dikatakan bahwa latar belakang pendidikan mempengaruhi kinerja karyawan. Sedangkan faktor pengalaman kerja, delapan responden mengatakan bahwa pengalam kerja mempengaruhi kinerja. Karena tanpa pengalaman kita tidak dapat mengembangkan pola pikir serta kinerja. Sedangkan dua responden mengatakan pengalaman kerja tidak mempengaruhi kinerja. Karna Work from Home adalah budaya kerja yang baru yang sebelumnya belum pernah dilakukan. Seperti rapat melalui Via Zoom. Dari jawaban responden tersebut dapat dikatakan bahwa pengalama kerja mempengaruhi kinerja karyawan.

Selanjutnya faktor latar belakang sosial budaya, terdapat enam responden mengatakan latar belakang sosial budaya mempengaruhi kinerja selama bekerja dari rumah (work from home). Perubahan yang awalnya bekerja dari kantor menjadi bekerja dari rumah (work from home). dimana pekerjaan lebih cepat diselesaikan apabila bekerja dari kantor karna koordinasi lebih mudah karna bertemu langsung dengan atasan dan rekan kerja. Berbeda dengan Work From Home dimana pekerjaan lebih lambat terselesaikan karna banyak kendala seperti jaringan internet yang kurang baik sehingga koordinasi menjadi lambat. Sedangkan empat responden lainnya mengatakan sebaliknya. karna harus beradaptasi dengan perubahan-perubahan budaya kerja baru apalagi ditengah pandemi pada saat ini. Dari jawaban responden tersebut dapat dikatakan bahwa latar belakang sosial budaya mempengaruhi kinerja 
karyawan. Adapun faktor lingkungan kerja, semua responden menjawab faktor lingkungan kerja mempengaruhi kinerja selama bekerja dari rumah (work from home). Karena situasi dirumah masingmasing orang berbeda. Dimana tidak semuanya kondusif untuk bekerja. Akan tetapi dengan bekerja dari rumah atau Work From Home lebih fleksibel. Terutama pada saat bosan bekerja dapat berpindah tempat ke tempat yang menurut kita nyaman untuk bekerja. Selain itu selama Work from Home waktu bekerja juga fleksibel bisa disesuaikan. Yang terpenting saat Work from Home karyawan bisa tetap bertanggung jawab dengan pekerjaannya. Dari jawaban responden tersebut dapat dikatakan bahwa lingkungan kerja mempengaruhi kinerja karyawan.

Selain itu faktor kepemimpinan, terdapat sembilan responden yang mengatakan bahwa kepemimpinan mempengaruhi kinerja. Karna kepemimpinan berfungsi untuk mengatur hubungan antara atasan dan bawahan serta rekan kerja untuk bisa bekerjasama dengan baik dalam melaksanakan pekerjaan. Sedangkan satu responden mengatakan kepemimpinan tidak mempengaruhi kinerja selama bekerja dari rumah (work from home). Karna dari atasan sudah terlebih dahulu membagikan tugas yang akan dikerjakan. Dari jawaban responden tersebut dapat dikatakan bahwa kepemimpinan mempengaruhi kinerja karyawan. Berikutnya faktor umpan balik rekan kerja, semua responden menjawab bahwa umpan balik rekan kerja mempengaruhi kinerja. Work From Home sangat bergantung pada umpan balik rekan kerja. Apabila umpan balik cepat penyelesaian pekerjaan dapat tepat waktu pula begitupun sebaliknya. Dari jawaban responden tersebut dapat dikatakan bahwa umpan balik rekan kerja mempengaruhi kinerja karyawan.

Adapun faktor pengawasan dari atasan, terdapat delapan responden mengatakan pengawasan dari atasan mempengaruhi kinerja. Karna pengawasan yang ada bertujuan untuk melihat sejauh mana kinerja karyawan dalam mengerjakan tugas apakah sudah sesuai atau belum. Sedangkan dua responden mengatakan tidak mempengaruhi kinerja selama bekerja dari rumah (work from home). Karna harus tetap disiplin meskipun tidak diawasi secara langsung seperti pada saat Work From Office. Dari jawaban responden tersebut dapat dikatakan bahwa pengawasan mempengaruhi kinerja karyawan. Faktor sistem upah, semua responden mengatakan hal yang sama bahwa sistem upah mempengaruhi kinerja selama bekerja dari rumah (work from home). Karena pada saat Work From Home tidak mendapat uang makan dan transport sehingga mempengari kinerja karyawan. Dari jawaban responden tersebut dapat dikatakan bahwa sistem upah mempengaruhi kinerja karyawan selama bekerja dari rumah (work from home).

\section{Pembahasan}

Berdasarkan hasil penelitian menunjukkan bahwa tingkat kinerja karyawan yang bekerja dari rumah (work from home) menurun karna terkendala jaringan serta kurang fokus bekerja dari rumah sehingga hasil kerja tidak sesuai target. WFH telah memberikan keuntungan dan kerugian bagi karyawan dan organisasi atas penurunan produktifitas karyawan (Mungkasa, 2020; Purwanto, 2020). Hal tersebut dipengaruhi oleh beberapa faktor-faktor kinerja karyawan yang bekerja dari rumah selama pandemi Covid-19. Pertama motivasi, karyawan lebih termotivasi bekerja dari kantor dibandingkan di rumah karna pekerjaan dapat diselesaikan dengan cepat dan optimal pada saat di kantor. Motivasi sangat penting dalam meningkatkan kinerja karyawan, karena motivasi memberikan sebuah dorongan dan semangat untuk melaksanaakan sesuatu (Mandey \& Sahangggamu, 2014; Pratisardy \& Lukito, 2019). Kedua, bonus mempengaruhi karna pencapain target selama bekerja dari rumah kurang optimal sehingga berdampak pada pemberian bonus. Dan juga uang makan dan transport terpotong. Hal ini dikarenakan bonus itu sendiri merupakan suatu imbalam timbal balik yang saling menguntungkan perusahaan maupun karyawan (Asmalah, 2018; Mangkunegara, 2011; Nugraha \& Tjahjawati, 2018). Punishment, mempengaruhi karna dengan adanya sanksi kita bisa mengetahui dimana letak kesalahan kita dalam bekerja dan sebisa mungkin tidak mengulangi kesalahan yang sama. Usia, mempengaruhi karna beberapa karyawan agak sulit mengoperasikan Aplikasi Zoom. Semakin karyawan memiliki kemampuan mengoperasionalkan teknologi informasi maka akan semakin lancar melaksanakan Work From Home. Tetapi untuk karyawan yang kurang mahir dalam penguasaan teknologi dan informasi akan terkendala dalam melaksanakan Work From Home. Hal ini karena penguasaan teknologi informasi berpengaruh terhadap kesiapan kerja (Sihotang \& Santosa, 2019).

Latar belakang pendidikan, mempengaruhi karna latar belakang pendidikan merupakan salah kualifikasi untuk mengerjakan pekerjaan tertentu khusunya penggunaan aplikasi AT pada Perum Perumnas Regional VII Makassar. Pengalaman kerja, mempengaruhi karena tanpa pengalaman kita tidak dapat mengembangkan pola pikir serta kinerja. Latar belakang sosial budaya, mempengaruhi karna dengan adanya budaya kerja yang baru Work From Home dengan memanfaatkan alat teknologi yang ada sebagai alat komunikasi agar koordinasi tetap berjalan dengan baik dan mampu membuat kita lebih terlatih dalam penggunaan alat teknologi. Dengan adanya teknologi, bekerja dari rumah menjadi lebih 
fleksibel yang meningkatkan keseimbangan kehidupan dengan pekerjaan (Lisanti, 2014). Lingkungan kerja, mempengaruhi karna situasi dirumah kurang kondusif dan kurangnya fasilitas yang memadai seperti akses wifi sehingga mempengaruhi kinerja. Hal ini sejalan dengan penelitian Tuwinanto dan Dedi Rianto Rahadi yang mengatakan salah satu faktor yang mempengatuhi kinerja selama Work From Home adalah lingkungan kerja yang kurang kondusif (Tuwinanto \& Rahadi, 2021).

Kepemimpinan, mempengaruhi karna berfungsi untuk mengatur hubungan antara atasan dan bawahan serta rekan kerja untuk bisa bekerjasama dengan baik dalam melaksanakan pekerjaan sehingga berjalan dengan baik. Umpan balik rekan kerja, mempengaruhi karna Work From Home sangat bergantung pada umpan balik rekan kerja. Apabila umpan balik cepat penyelesaian pekerjaan dapat tepat waktu pula begitupun sebaliknya. Komunikasi menjadi tantangan terbesar saat melakukan work from home. Untuk itu harus selalu online dan mudah dihubungi, sehingga saat ada diskusi atau koordinasi menjadi lebih cepat (Fitriani, 2020; Widiyanti \& Wisayang, 2021). Frekuensi komunikasi juga harus dilakukan sesering mungkin untuk menjaga komunikasi antar tim agar tidak terjadi miskomunikasi. (Dewayani, 2020) Pengawasan dari atasan, mempengaruhi karna pengawasan selama Work From Home bertujuan untuk memastikan apakah proses kerja sudah berjalan sesuai prosedur yang telah ditetapkan. Sistem upah, mempengaruhi karena pada saat Work From Home kita tidak mendapat uang makan dan transport. Selain faktor-faktor yang di uraikan di atas, ada beberapa faktor lain yang mempengaruhi kinerja karyawan selama bekerja dari rumah (work from home) yaitu jaringan internet yang kurang stabil, sehingga menghambat kita pada saat koordinasi melalui alat teknologi seperti Via Zoom. Fasilitas yang kurang memadai, salah satunya tidak memiliki akses wifi yang jaringannya lebih stabil. Target penjualan yang ingin dicapai, untuk mencapai target harus meningkatkan kinerja serta memanfaatkan alat teknologi untuk penjualan meskipun Work From Home. Ruang gerak terbatas, sehingga mempengaruhi produktifitas kerja. Miskomunikasi, kemungkin akan sering terjadi dan kerap kali menjadi salah satu tantangan terbesar saat Work From Home. Terkadang ada rekan kerja yang susah dihubungi meskipun di jam bekerja sehingga sulit untuk koordinasi.

Temuan ini diperkuat dengan temuan sebelumnya yang menyatakan bahwa selama bekerja dari rumah terdapat beberapa kendala yang membuat pekerjaan kurang maksimal dikerjakan (Purwanto, 2020). Salah satunya jaringan internet yang kurang stabil, terbatasnya kuota internet, tidak memiliki akses pendukung seperti wifi dimana jaringan nya lebih stabil, beberapa karyawan kurang mahir dalam mengoperasikan aplikasi Zoom untuk koordinasi serta uang makan dan transport juga terpotong (Anugrah \& Priyambodo, 2021; Mungkasa, 2020). Dari hasil pembahasan untuk kelancaran dalam mengerjakan tugas selama bekerja dari rumah (work from home) sebaiknya uang makan dan uang transport tidak dipotong, tetapi diberikan kepada karyawan untuk membayar biaya wifi dan bisa untuk biaya kuota internet apabila karyawan yang lain tidak memiliki akses wifi di rumah. Selain itu memberikan simulasi untuk pengoperasian alat teknologi yang digunakan selama bekerja dari rumah (work from home) agar menunjang kinerja karyawan menjadi lebih baik.

\section{SIMPULAN}

Tingkat kinerja karyawan selama bekerja dari rumah (work from home) pada Perum Perumnas Regional VII Makassar menurun atau kurang optimal. Karna terkendala jaringan dalam koordinasi terkait pekerjaan sehingga hasil kerja belum sesuai karna target belum tercapai, serta kurang fokus pada saat bekerja dari rumah (work from home). Sedangkan faktor-faktor yang mempengaruhi kinerja karyawan selama bekerja dari rumah (work from home) pada Perum Perumnas Regional VII Makassar yaitu motivasi, bonus, punishment, usia, latar belakang pendidikan, pengalaman kerja, latar belakang sosial budaya, lingkungan kerja, kepemimpinan, umpan balik rekan kerja, pengawasan dari atasan serta sistem upah. Adapun faktor lain yang mempengaruhi kinerja yaitu jaringan internet yang kurang stabil, fasilitas kurang memadai, kepuasan kerja, target penjualan, ruang gerak terbatas dan miskomunikasi.

\section{DAFTAR PUSTAKA}

Anugrah, P. G., \& Priyambodo, B. A. (2021). Peran Work-Life Balance terhadap Kinerja Karyawan yang Menerapkan Work From Home ( WFH ) di Masa Pandemi COVID-19: Studi Literatur. Fakultas Pendidikan Psikologi Universitas Negeri Malang, 19(April), 340-349.

Arianto, B. (2021). Dampak Pandemi COVID-19 terhadap Perekonomian Dunia. Jurnal Ekonomi Perjuangan, 2(2), 212-224. https://doi.org/10.36423/jumper.v2i2.665.

Arief Kresna dan Juni Ahyar. (2020). Pengaruh Physical Distancing dan Social DistancingTerhadap Kesehatan Dalam Pendekatan Linguistik. Jurnal Syntax Transformation, 1(4), 14-18. http://jurnal.globalhealthsciencegroup.com/index.php/JPPP/article/download/83/65\%0Ahttp:/ 
/www.embase.com/search/results?subaction=viewrecord\&from=export\&id=L603546864\%5Cn http://dx.doi.org/10.1155/2015/420723\%0Ahttp://link.springer.com/10.1007/978-3-319-76.

Asmalah, L. (2018). Pengaruh Motivasi Dan Disiplin Kerja Terhadap Kinerja Guru Sekolah Dasar Wilayah Kecamatan Parung Panjang Kabupaten Bogor. JENIUS (Jurnal Ilmiah Manajemen Sumber Daya Manusia), 2(1), 55-74. https://doi.org/10.32493/jjsdm.v2i1.1935.

Astuti, W. S., Sjahruddin, H., \& Purnomo, S. (2019). Pengaruh Reward dan Punishment Terhadap Kinerja Karyawan. 1(1), 31-46. https://doi.org/10.31227/osf.io/pjkw5.

Bukhari, K., Efendi, Z. M., \& Jama, J. (2019). The Development of Physical and Sport Education Learning Model by Using Small Games. Journal of Physics: Conference Series, 1387(1). https://doi.org/10.1088/1742-6596/1387/1/012014.

Darmalaksana, W., Hambali, R. Y. A., Masrur, A., \& Muhlas. (2020). Analisis Pembelajaran Online Masa WFH Pandemic Covid-19 sebagai Tantangan Pemimpin Digital Abad 21. Karya Tulis Ilmiah (KTI) Masa Work From Home (WFH) Covid-19 UIN Sunan Gunung Djati Bandung Tahun 2020, 1(1), 1-12. http://digilib.uinsgd.ac.id/id/eprint/30434.

Dewayani, T. (2020). Bekerja dari Rumah (Work From Home) Dari Sudut Pandang Unit Kepatuhan Internal. Www.Djkn.Kemenkeu.Go.Id.

Endah Yuliani, \& Romadhiyana Kisno Saputri. (2021). Perbandingan Penggunaan Platform Google Classrom dan Grup Whatsapp Dalam Pembelajaran Online Selama Pandemi Covid-19. Jurnal Educatio FKIP UNMA, 7(1), 238-243. https://doi.org/10.31949/educatio.v7i1.934.

Filatrovi, E. W., Kurniawati, N. I., \& Setiyono, T. A. (2021). Mengelola Kinerja Karyawan Bank Syariah Di Masa Pandemi Covid-19 Melalui Islamic Work Ethics. Jurnal Ilmiah Ekonomi Islam, 7(02), 1140-1146. https: //doi.org/10.29040/jiei.v7i2.2744.

Fitriani, Y. (2020). Analisa Pemanfaatan Learning Management System (Lms) Sebagai Media Pembelajaran Online Selama Pandemi Covid-19. Journal of Information System, Informatics and Computing, 4(2), 1. https://doi.org/10.52362/jisicom.v4i2.312.

Hermawati, R., \& Indriyani, S. (2019). Pengaruh Rekrutmen Dan Kompensasi Terhadap Kinerja Karyawan Pada PT. Sinergi Inti Pelangi. JENIUS (Jurnal Ilmiah Manajemen Sumber Daya Manusia), 3(1), 24 41. https://doi.org/10.32493/JJSDM.v3i1.3366.

Koh, W. C., Naing, L., \& Wong, J. (2020). Estimating the impact of physical distancing measures in containing COVID-19: An empirical analysis. International Journal of Infectious Diseases, 100, 42-49. https://doi.org/10.1016/j.ijid.2020.08.026.

Kusuma, R. (2011). Evaluasi Penerapan Sistem Informasi Manajemen Keimigrasian (SIMKIM) Kantor Imigrasi Kelas I Yogyakarta: Pendekatan Kualitatif. Jurnal Fisip Umrah, 1.(1), 287-295. https: //doi.org/10.1016/j.sbspro.2015.04.

Lau, L. L., Hung, N., Go, D. J., Ferma, J., Choi, M., Dodd, W., \& Wei, X. (2020). Knowledge, attitudes and practices of COVID-19 among income-poor households in the Philippines: A cross-sectional study. Journal of Global Health, 10(1), 1-11. https://doi.org/10.7189/JOGH.10.011007.

Lisanti, Y. (2014). ICT Memungkinkan Orang Bekerja dari Rumah: Studi Kasus pada Bank dan Kursus Online. ComTech: Computer, Mathematics and Engineering Applications, 5(1), 14. https://doi.org/10.21512/comtech.v5i1.2575.

Mandey, S., \& Sahangggamu, P. (2014). Pengaruh Pelatihan Kerja, Motivasi, Dan Disiplin Kerja Terhadap Kinerja Karyawan Pada Pt. Bank Perkreditan Rakyat Dana Raya. Jurnal Riset Ekonomi, Manajemen, Bisnis Dan Akuntansi, 2(4), 514-523. https://doi.org/10.35794/emba.v2i4.6359.

Mangkunegara, P. A. (2011). Pengaruh Kompensasi Terhadap Kinerja Karyawan Di Pt. Global (Pt.Gm). Jurnal Ilmiah MEA (Manajemen, Ekonomi, \& Akuntansi), 3(2), 184-190. https://doi.org/10.31955/mea.vol3.iss2.pp18.

Marroquín, B., Vine, V., \& Morgan, R. (2020). Mental health during the COVID-19 pandemic: Effects of stayat-home policies, social distancing behavior, and social resources. Psychiatry Research, 293(July), 113419. https://doi.org/10.1016/j.psychres.2020.113419.

Muhyiddin. (2020). Covid-19, New Normal, dan Perencanaan Pembangunan di Indonesia. Jurnal Perencanaan Pembangunan: The Indonesian Journal of Development Planning, 4(2), 240-252. https://doi.org/10.36574/jpp.v4i2.118.

Mungkasa, O. (2020). Bekerja dari Rumah (Working From Home/WFH): Menuju Tatanan Baru Era Pandemi COVID 19. Jurnal Perencanaan Pembangunan: The Indonesian Journal of Development Planning, 4(2), 126-150. https://doi.org/10.36574/jpp.v4i2.119.

Nasrih, M. L. (2016). Analisis Hubungan Kepuasan Kerja Terhadap Prestasi Kerja Karyawan. Al-Iqtishad: Journal of Islamic Economics, 2(1). https://doi.org/10.15408/aiq.v2i1.2477.

Nasution, D. A. D., Erlina, \& Muda, I. (2020). Dampak Pandemi COVID-19 terhadap Perekonomian Indonesia. Jurnal Benefita, 5(2), 212 - 224. https://doi.org/10.22216/jbe.v5i2.5313. 
Nugraha, A., \& Tjahjawati, S. S. (2018). Pengaruh Kompensasi Terhadap Kinerja Karyawan. Jurnal Riset Bisnis Dan Investasi, 3(3), 24. https://doi.org/10.35697/jrbi.v3i3.942.

Pfattheicher, S., Nockur, L., Böhm, R., Sassenrath, C., \& Petersen, M. B. (2020). The Emotional Path to Action: Empathy Promotes Physical Distancing and Wearing of Face Masks During the COVID-19 Pandemic. Psychological Science, 5, 095679762096442. https://doi.org/10.1177/0956797620964422.

Pratisardy, E., \& Lukito, H. (2019). Dampak Rekrutmen, Seleksi, dan Motivasi Terhadap Kinerja Karyawan PT Bank XYZ TBK Cabang Padang. Jurnal Ekonomi Dan Bisnis, 21(1). https://doi.org/10.30811/ekonis.v21i1.896.

Purwanto, A. (2020). Studi eksplorasi Dampak WFH Terhadap Kinerja Guru. Journal of Education, Psychology and Counseling, 2(1), 92-100.

Scheffer, M., \& Markus, K. (2016). Pengaruh Komite Audit, Kepemilikan Institusional, Dewan Komisaris, Ukuran Perusahaan (size), Leverage (DER) Dan Profitabilitas (ROA) Terhadap Tindakan Penghindaran Pajak (Tax Avoidance) Pada Perusahaan Perbankan Yang Listing BEI Periode Tahun 2011-2013. Journal Of Accounting, 2(2), 3345-3356.

Sihotang, F. H., \& Santosa, D. S. S. (2019). Pengaruh prestasi belajar, penguasaan teknologi informasi dan pengalaman organisasi terhadap kesiapan kerja. Ecodunamika, 2(1), 1-6.

Syatoto, I. (2018). Pengaruh Rekrutmen dan Pelatihan Terhadap Kinerja Karyawan Pada PT. Radana Bhaskara Finance. Tbk. JENIUS (Jurnal Ilmiah Manajemen Sumber Daya Manusia), 1(2). https: //doi.org/10.32493/JJSDM.v1i2.927.

Talevi, D., Socci, V., Carai, M., Carnaghi, G., Faleri, S., Trebbi, E., Bernardo, A. D. I., Capelli, F., \& Pacitti, F. (2020). Mental health outcomes of the CoViD-19 pandemic Gli esiti di salute mentale della pandemia di CoViD-19. Riv Psichiatr, 55(3), 137-144. https://doi.org/10.1708/3382.33569.

Tuwinanto, T., \& Rahadi, D. R. (2021). Work From Home Dimasa Pandemi, Efektifkah ? Jurnal Manajemen Bisnis, 18(1), 86-95. https://doi.org/10.38043/jmb.v18i1.2736.

Widiyanti, \& Wisayang, V. R. W. (2021). Inovasi Dan Kreativitas Kang Bagong Catering Semarang Di Tengah Pandemi. Praxis, 3(2), 82. https://doi.org/10.24167/praxis.v3i2.3034.

Wijonarko, G., Aribowo, H., Winarto, A., \& Ramadoni, W. (2020). Perancangan Program Pelatihan Karyawan Dalam Rangka Mendukung Produktivitas. Jurnal EKSEKUTIF, 17(1), 35-46. https://jurnal.ibmt.ac.id/index.php/jeksekutif/article/view/254. 